\title{
Wisconsin Vegetation Database - plant community survey and resurvey data from the Wisconsin Plant Ecology Laboratory
}

\author{
Donald M. Waller, Kathryn L. Amatangelo, Sarah Johnson \& David A. Rogers
}

\begin{abstract}
Legacy data provide valuable baselines for assessing ecological changes. Excellent baseline data for Wisconsin's plant communities exist because of the surveys conducted by J.T. Curtis and colleagues (the Wisconsin Plant Ecology Laboratory or PEL) in the 1940s and 1950s. They surveyed > 2,000 sites to test how plant community composition varies along environmental gradients. These sites include upland and lowland forests, prairies, savannas, meadows, sand barrens, dunes, fens, and bogs. They devised new techniques to sample and compare plant communities. Their data include species lists and often quantitative data on occurrences and tree sizes. At intensively sampled prairies and savannas, data include cover and/or the composition of quadrats. At forested sites, researchers characterized the overstory by recording tree identity and measuring size and spacing using plotless methods. For the understory, they tallied all vascular species present in 20 (occasionally 40) spaced $1-\mathrm{m}^{2}$ quadrats. Subsequent PEL researchers have resurveyed $>500$ of these sites. The original quadrats and sites were not marked, requiring that resurveys approximate the original locations. Sampling uses either the original or more intensive protocols. We have characterized environmental conditions at many sites (soil chemistry, exotic earthworms, deer browse, and landscape conditions). We also now measure functional traits on many species. Our goals are to test theories of community assembly and assess how plant traits interact with patch size and landscape conditions to affect species and community dynamics. We have also redesigned sampling methods. The many sites and species provide great statistical power to characterize ecological changes and evaluate the factors driving these changes. These results serve to inform the public about ecological change and improve our ability to manage these communities wisely. Both the new and the legacy data are stored in the database Wisconsin Vegetation Database (GIVD ID NA-US-008).
\end{abstract}

Keywords: beech forest; cedar glade; floodplain forest; groundlayer; long-term data; overstory; plant community; prairie; upland forest.

Nomenclature: Wisconsin state herbarium's checklist ('WisFlora') available at http://botany.wisc.edu/herbarium as accessed in the 2000 s by each study described.

Abbreviations: $\mathrm{DBH}=$ diameter breast height; FIA $=$ Forest Inventory and Analysis program of the USDA Forest Service; PEL $=$ Plant Ecology Lab of the University of Wisconsin - Madison; UP = Upper Peninsula of Michigan.

Received: 16 November 2010 - Accepted: 9 December 2011 - Co-ordinating Editor: Robert K. Peet.

\section{Background}

John T. Curtis founded the Plant Ecology Laboratory (PEL) at the University of Wisconsin - Madison in the 1940s to investigate the nature of plant communities and how these varied over environmental gradients and among sites. Originally, he and Robert Whittaker $(1956,1975)$ independently sought to measure how the abundances of individual species changed along environmental gradients in order to test Henry Gleason's (1926) concept that species respond separately (individualistically) to shifts in environmental conditions. Given such individual responses, we expect community composition to vary continuously along environmental gradients, an idea that Curtis elaborated in his 'continuum' concept (Brown \& Curtis 1952). Curtis, Whittaker, and others also developed new sampling methods (e.g., Cottam \& Curtis 1949; Cottam \& Curtis 1956) and multivariate methods to analyze and compare plant communities (e.g., Bray \& Curtis 1957) still in common use by ecologists.

Curtis and his colleagues fanned out across Wisconsin between 1947 and the late 1950s, eventually collecting a rich legacy of qualitative and quantitative field data from more than 2,000 sites (Fig. 1; Tables 1 and 2). These surveys provided the basis for the detailed descriptions and analyses of Wisconsin's plant communities contained in a string of MS and $\mathrm{PhD}$ theses. Curtis ably summarized the vast amount of information in his landmark book, The vegetation of Wisconsin: An ordination of plant communities (Curtis 1959). This text focused both on describing the community types found across the state and describing summary trends. These strongly supported Gleason's individualistic hypothesis.

From its beginning, the Plant Ecology Laboratory (PEL) was an institution that integrated two rationales: a physical place for study and data files and a body of accumulated theory and understanding about how species relate to their natural 
environments (Loucks 2009). John T. Curtis wanted this knowledge to improve human use and appreciation for those landscapes. His plan to systematically study the vegetation throughout Wisconsin emerged in 1946-47 (Burgess 1993). Several students pursued the initial research on forests and forest herbs, including Forest Stearns, Grant Cottam, Bob McIntosh, Phil Whitford, and Robert Brown. Each worked on similar questions but in different communities or parts of the state. They employed quantitative and experimental approaches where possible. A second cohort of students included David Archbald, Max Partch, John Butler, Orlin Anderson, and Bonita Neiland. They tackled the grassland and prairie communities. Other students quantified communities of soil-fungi (Martha Christensen), aquatic macrophyte, and lichen communities. An important aspect of the sampling by Curtis and his students was its focus on understory as well as over- story forest diversity (Struik \& Curtis 1962). Because most of the plant diversity in temperate forests occurs in the understory, these data provide a much fuller picture of ecological change and greater statistical power for understanding the trajectories of community change across Wisconsin's changing landscapes. Many historical studies of forest change have focused instead on the overstory, literally missing the forest for the trees.

\section{Wisconsin Vegetation Database}

Scope: This unique data set includes sites from multiple habitat types resampled $50+$ years apart. $>1000$ sites were sampled throughout Wisconsin in the 1950s by John Curtis et al., and 350 of these have been resampled. The 1950s tree data were collected using distance-based methods and the presence of groundlayer species was recorded within $\sim 201-\mathrm{m}^{2}$ quadrats. The methods used in the 2000 s vary by habitat, but the groundlayer was sampled more intensively at $40-1201-m^{2}$ quadrats.

Status: completed and continuing

Period: $1945-2008$

Database manager(s): Donald Waller (dmwaller@wisc.edu)

Owner: University of Wisconsin Plant Ecology Laboratory

Web address: http://www.botany.wisc.edu/PEL/

Availability: according to a specific agreement

Database format(s): MS Access

Publication: [NA]

Plot type(s): normal plots; time series

Non-overlapping plots: 2,582

Total plot observations: 2,582$$
\text { Period: } 1945-2008
$$

Countries: US: $100.0 \%$

Forest: [NA] - Non-forest: [NA]

Guilds: all vascular plants: $96 \%$; only trees and shrubs: $4 \%$

Environmental data: microrelief: $2 \%$; soil depth: $2 \%$; soil pH: $25 \%$; other soil attributes: $25 \%$; land use categories: $25 \%$

Performance measure(s): presence/absence only: $30 \%$; number of individuals: $70 \%$; measurements like diameter or height of trees: $100 \%$

Geographic localisation: GPS coordinates (precision $25 \mathrm{~m}$ or less): $50 \%$; political units or only on a coarser scale (>10 km): $100 \%$

Sampling periods: 1940-1949: 15.0\%; 1950-1959: 65.0\%; 2000-2009: $20.0 \%$

Information as of 2012-07-21; further details and future updates available from http://www.givd.info/ID/NA-US-008

\section{Curtis legacy data}

The original field data sheets and handtallied summaries are archived in the Ecology Records Room in Birge Hall on the University of Wisconsin - Madison campus. These surveys covered a wide geographic range (Fig. 1) as well as the range of Wisconsin's native plant communities. Individual survey sites were chosen to represent homogenous samples of relatively undisturbed vegetation (see below). All sampled sites met a Chisquare test of homogeneity and were at least 6 ha in size. Curtis also admitted, however, that subjective choices could not be avoided altogether in choosing stands, noting "the most important decision made by an ecologist is that made when he stops his car" (Curtis 1959: 70).

For most sites sampled, we have a hand-drawn map showing the location of the stand relative to local features and a tally of all the species observed there. Data on the open communities usually also include information on percent cover by species. Forested sites (Plates A, B, C) were also sampled quantitatively, typically including data on the sizes and frequencies of $\sim 80$ overstory trees sampled via the point-quarter or random-pairs method (see below), as well as the occurrence (presence/absence) of all forest understory plant species in each of 20 (occasionally 40) spaced 1- $\mathrm{m}^{2}$ quadrats (Fig. 3 ). Because the original researchers rarely collected voucher specimens for deposit in the UW-Herbarium (WIS), we have encountered difficulties when we have sought to verify their identifications or match taxonomic categories when species designations have changed (see below). In addition, the lack of historical specimens precludes being able to monitor genetic changes in these plant populations over time (Hansen et al. 2012).
Many of these original data have been digitized and are available for public inspection and use. These efforts began in the early 1990s when Charles Umbanhowar (now at St. Olaf College) encoded data from a broad set of sites as Lotus 123 spreadsheets (Umbanhower 2001). These files cover the full range of communities surveyed by the original PEL teams and are available at: http://www.stolaf.edu/

people/ceumb/PEL.html. However, some data were not digitized due to funding constraints. In addition, users should be aware of occasional numerical errors and that some taxonomic assignments are suspect, particularly in challenging groups like Carex and Viola. This led more recent researchers to re-digitize the original survey data for the particular community types they were studying. 


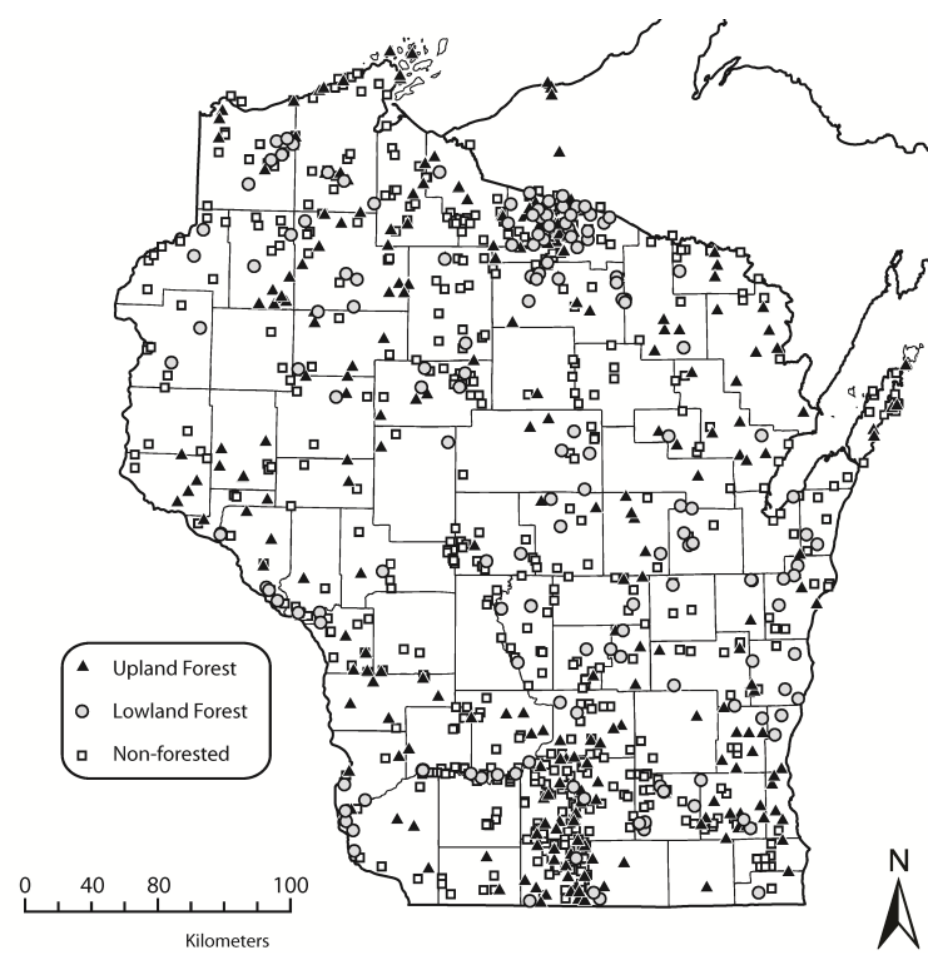

Fig. 1: Locations of the sites in Wisconsin and the western Upper Peninsula of Michigan sampled for plant community composition by John Curtis and his colleagues in the 1940 s and 1950 s.

\section{Resurveys}

Since the 1990s researchers at the University of Wisconsin have relocated and resampled over 500 of the sites originally surveyed by Curtis and his students (Table 2). This work began with the pioneering research of Leach \& Givnish (1996) on 54 prairie remnants. Subsequent resampling has focused on various types of forest (Fig. 2) starting with the upland forests of northern Wisconsin and the western Upper Peninsula of Michigan (Rooney et al. 2004b, Wiegmann \& Waller 2006, Amatangelo et al. 2010). Dave Rogers then led efforts to resurvey the upland oak-hickory and maple-basswood forests of southern Wisconsin and the beech forests of eastern Wisconsin (Rogers et al. 2008, Rogers et al. 2009). Work is now continuing with the lowland (floodplain) forests of southern Wisconsin (S. Johnson et al. unpubl.). We have also begun to resurvey the pine barrens and soil micro-fungi at a few of the northern upland forests surveyed by Martha Christensen $(1969,1989)$. For further background on the history of the PEL, the various community types sampled, and the data available from these studies, see http://www.botany.wisc.edu/PEL/. For a remarkably complete and well-organized set of 1,200 photographs of these com- munities and many of their constituent species, see http://uwdc.library.wisc. edu/collections/EcoNatRes/KlineV.

Contemporary PEL researchers work hard to collect extensive and accurate data from the Curtis sites. This effort includes carefully identifying all plant species in more than 20,000 quadrats using keys from Gleason \& Cronquist (1991) and Voss $(1972,1985,1996)$ and the WIS Herbarium's species list. To ensure accuracy, we collect any questionable species for verification by experts and deposit these as vouchers at the state herbarium (WIS). Changes in taxonomic nomenclature over the past 50+ years (including the splitting of some species and combining of others) and uncertainty regarding taxonomic determinations of $50+$ years ago make it essential that we carefully 'synchronize' taxonomic identifications. When entering the historical data into our digital database, we cross-checked all names against the original field data sheets, correcting a few errors PEL staff made in transferring these data. From these, we compiled species lists, translating the various names, abbreviations, and codes used in the original data to current nomenclature as set by the UW herbarium (http://botany.wisc.edu/herbarium). In most cases, this taxonomic synchronization only involved updating names (e.g.,
Hepatica acutiloba to Anemone acutiloba - also known as Hepatica nobilis var. acuta in the USDA Plants database). In other cases, however, the original PEL data lumped species that are now split, split taxa that are now combined, or applied inconsistent levels of taxonomic resolution among different observers. In these cases, we are often forced to merge taxa into the next highest taxonomic group (e.g. Carex spp., Dryopteris carthusiana, Botrychium multifidum). We took great care to avoid inappropriate lumping of taxa so as not to obscure ecological and regional differences in similar taxa as in the Quercus rubra complex, Corylus americanalcornuta, Anemone acutilobalamericana, Ribes missouriensis/cynosbati, and Trillium cernuum/flexipes. Species within such groups often have distinctive ecological requirements or ranges. Lumping such species can impair our ability to analyze and interpret these data. In addition, as different levels of taxonomic resolution are appropriate for different types of analysis, we make these decisions carefully using our knowledge of species' habits and habitats.

\section{Original field survey methods}

\section{Forests}

Original PEL researchers focused considerable time and attention on sampling the major forest types across Wisconsin and the western UP of Michigan (Fig. 1). Landscapes in southern and northern Wisconsin differ conspicuously across a 'tension zone' in forest type, component species and landscape composition (Curtis 1959). Forests represent the matrix in the northern third of the state. Considerable forest cover also exists in the western and southwestern areas of the state that were never glaciated but forests are small and highly fragmented in southeastern Wisconsin. To ensure adequate and representative samples, PEL researchers only sampled forest stands that were all at least 6 ha (15 acres) in size, of uniform topography, and relatively homogenous (Curtis 1959). They generally chose stands unaffected by recent grazing or logging (i.e., $>10 \%$ of the canopy removed). However, some disturbed stands were specifically chosen in order to make comparisons (e.g., the 'deer yard' and 'nondeer-yard' sites in Table 2). Methods used in all forest types, however, were quite similar. 


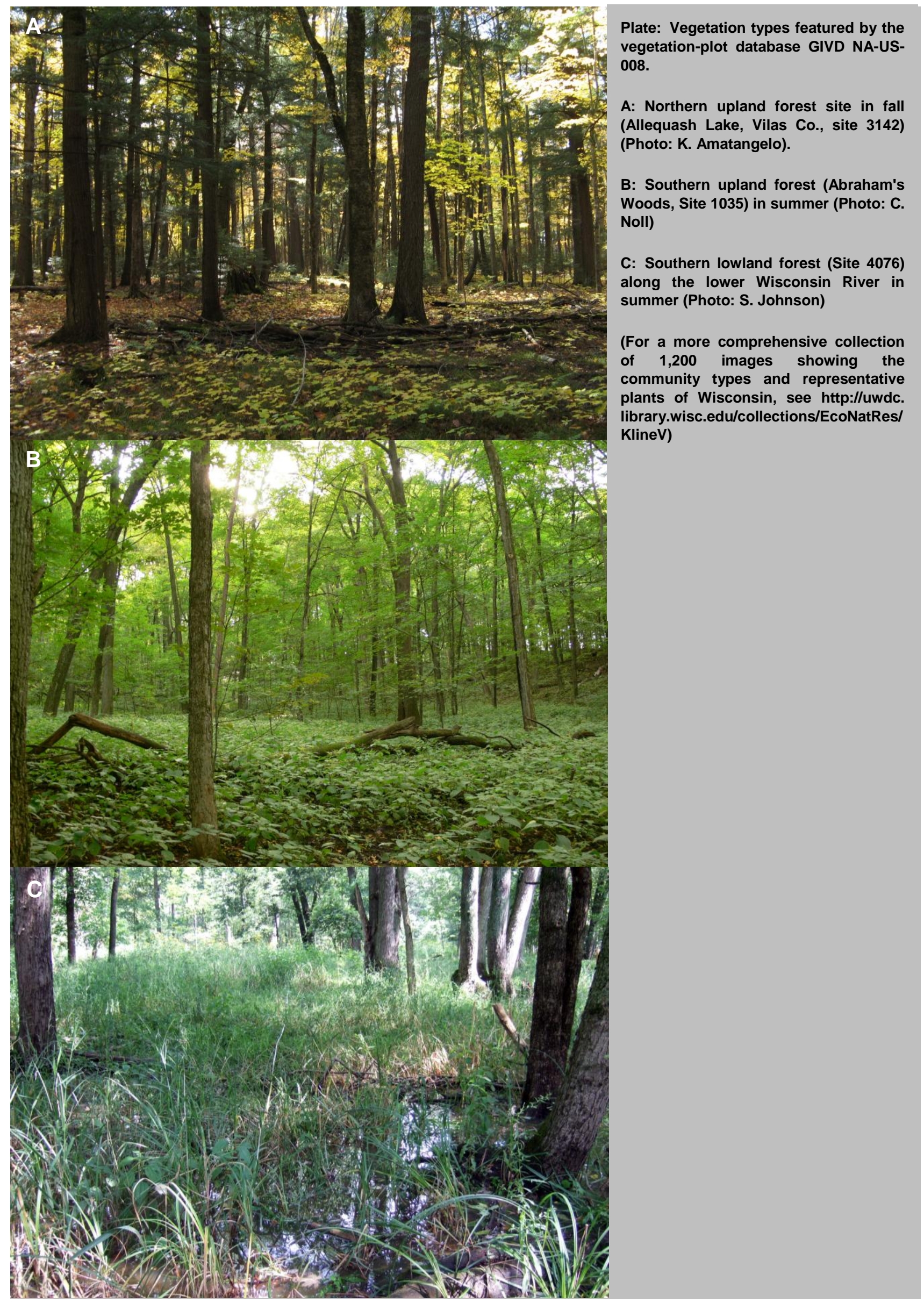


Table 1: Researchers working with J. T. Curtis who were primarily responsible for collecting initial PEL data within each listed community type.

\begin{tabular}{ll}
\hline \multicolumn{1}{c}{ Community } & \multicolumn{1}{c}{ Researchers } \\
\hline Northern Upland Forests & F.W. Stearns, R.T. Brown, M.L. Gilbert, W.E. Randall, O. Anderson \\
Northern Lowland Forests & H.A. Goder, J.J. Jones, E.M. Christensen, R.T. Ward \\
Southern Upland Forests & R.P. Mclntosh, P.W. Whitford, G. Cottam, M.L. Partch, M.L. Gilbert, W.E. Randall \\
Southern Lowland Forests & G.H. Ware, R.A. Dietz \\
Prairies & O. Anderson, M.L. Partch, P. Green, L.D. Bard, B.G. Wagner, H.C. Greene \\
Oak Savannas & J. R. Bray, G. Cottam, A.B. Stout \\
Pine Barrens & R.T. Brown \\
Boreal Forest & P.F. Maycock \\
Cedar Glades & J.R. Bray \\
Sedge Meadows & H.C. Greene \\
Beach, Dunes, and Cliffs & H.C. Greene \\
Apostle Islands & E.W. Beals \\
\hline
\end{tabular}

Researchers first performed a walkthrough survey to tally a full list of the species present. Inside the stand and at least $30 \mathrm{~m}$ from the forest edge, the researchers then paced out either a succession of linear, usually parallel, transects (e.g., at the southern lowland and Apostle Island sites), a large three-sided $\mathrm{U}$, or a four-sided box (at most of the northern and southern upland forest sites) by turning $90^{\circ}$ at the end of each transect (Fig. 3). These transects varied in length, expanding or contracting to accommodate the size of the stand. They were usually $\sim 600-1,000 \mathrm{~m}$ in length in total. Along these transects, they sampled trees at 40 points located every $15-20 \mathrm{~m}$. At each point, they noted the identity and size (diameter breast height, or DBH) of either the two or four nearest trees (woody plants $>10 \mathrm{~cm}$ in DBH) using the randompairs or point-quarter method, respectively (Cottam \& Curtis 1949, 1956). Such "plotless" methods can provide rapid and efficient estimates of tree basal area and density (Curtis 1959). However, these methods assume that sampled trees have a random distribution. This could introduce a bias if trees are actually dispersed in a regular or hyper-dispersed pattern (as commonly observed). Our comparison of field methods, however, detected only a small difference $(6.4 \%)$ in total tree density (all species combined). Nevertheless, area-based methods may be more reliable for calculating basal area and tree density, particularly for individual species and when the amount of spatial aggregation changes between censuses. At 20 of the 40 sampling points, researchers also recorded the presence/absence of all herb, shrub, vine, and tree seedling species present within a $1-\mathrm{m}^{2}$ quadrat. These data when tallied over all quadrats provide quantitative estimates of plant frequency. They also obtained soil samples and estimated canopy coverage at some sites.

\section{Prairie and savanna grasslands}

Prairie and savanna grasslands once covered large areas of western and southern Wisconsin but were seriously reduced in cover and extent by the time of the original PEL surveys (Waller and Rooney 2008). They hosted an abundance of plant species and great biomass but were mostly converted to row agriculture in the 19th century. This gave PEL researchers a sense of urgency to sample as many highquality remnant stands as possible (Curtis 1959). Curtis \& Greene (1949) first sampled 65 prairie sites in the late 1940s, characterizing the vegetation from species lists based on two to three visits per growing season. They noted conspicuous differences in species composition from the dry, thin-soiled prairies on limestone ridges and hillsides to mesic sites with deep and well-drained loam soils to the wet prairies near springs and on floodplains. They characterized five distinct types of prairie community along this continuum using ten indicator species for each.

Savannas represented one of the most widespread communities before European settlement (over 4 million ha). Roger Bray (1955) sampled and characterized 59 savanna grasslands in southwestern Wisconsin using quadrats $\left(0.25-1 \mathrm{~m}^{2}\right)$ at 52 of these and comprehensive species lists from the others (Table 2). He also surveyed the scattered trees and used both samples to distinguish oak openings, oak barrens, cedar glades, and other types. Curtis (1959) noted that they were unable to sample any wet or wet-mesic sites that had not been used as pasture and ranked oak savannas with intact understories as the rarest community type in Wisconsin.

\section{Other communities}

Other communities were sampled by Curtis and colleagues in their original surveys using a variety of methods (Curtis 1959, Table 2). For example, they sampled the aquatic sites by simply listing the species present or sampling in quadrats that ranged in size from 100 to 300 square inches $\left(0.064-0.194 \mathrm{~m}^{2}\right)$. Because these methods varied so much among and sometimes within community types, we present only the summary tally of them in Table 2. 
Table 2: Tally of the 38 community types originally sampled by J.T. Curtis and his students including the numbers of sites originally surveyed, the number re-surveyed up through 2011 , and the original sampling methods used. NA = not applicable. Resurvey methods sometimes differ from the original methods (see text).

\begin{tabular}{|c|c|c|c|c|c|c|c|}
\hline \multirow{2}{*}{ Community Type } & \multirow{2}{*}{$\begin{array}{c}\text { Number } \\
\text { Sampled by } \\
\text { Curtis et al. }\end{array}$} & \multicolumn{3}{|c|}{$\begin{array}{c}\text { Original Herb Sampling Meth- } \\
\text { ods }\end{array}$} & \multirow{2}{*}{$\begin{array}{l}\text { Tree Sampling } \\
\text { Method }\end{array}$} & \multirow{2}{*}{$\begin{array}{l}\text { Number Re- } \\
\text { Sampled }\end{array}$} & \multirow{2}{*}{$\begin{array}{l}\text { Resampling research- } \\
\text { er(s) }\end{array}$} \\
\hline & & Quadrats & Presence & None & & & \\
\hline Alder Thicket & 11 & & 11 & & NA & 0 & \\
\hline Apostle Islands Forests & 68 & 68 & & & Point-quarter & 32 & Johnson \\
\hline Aquatic & 69 & 69 & & & NA & 0 & \\
\hline Beech Forests & 40 & 36 & 2 & 2 & Random pairs & 24 & Rogers \\
\hline Boreal Forests & 112 & 102 & 10 & & Point-quarter & 21 & Rogers \\
\hline Bracken Grassland & 27 & & 27 & & NA & 0 & \\
\hline Cedar Glade & 8 & 7 & 1 & & Random pairs & 6 & Mills \\
\hline Conifer Swamp & 117 & 101 & & 16 & unknown & 2 & Johnson \\
\hline Emergent Aquatic & 45 & & 45 & & NA & 0 & \\
\hline Fen & 12 & & 12 & & NA & 0 & \\
\hline Grazed Southern Upland & 50 & 50 & & & Point-quarter & 0 & \\
\hline $\begin{array}{l}\text { Logged Southern Upland For- } \\
\text { est }\end{array}$ & 71 & 68 & 2 & 1 & Point-quarter & 24 & Rogers \\
\hline Northern Dry Weed Community & 21 & & 21 & & NA & 0 & \\
\hline Northern lowland - Deer Yard & 38 & 35 & 2 & 1 & Random pairs & 16 & Bushman \\
\hline $\begin{array}{l}\text { Northern lowland - Non Deer } \\
\text { Yard }\end{array}$ & 34 & 26 & & 8 & Random pairs & 19 & Bushman \\
\hline $\begin{array}{l}\text { Northern Mesic Weed Com- } \\
\text { munity }\end{array}$ & 10 & & 10 & & NA & 0 & \\
\hline $\begin{array}{l}\text { Northern Railroad Weed } \\
\text { Community }\end{array}$ & 15 & & 15 & & NA & 0 & \\
\hline Northern Upland Forest & 207 & 130 & 41 & 36 & Random pairs & 89 & $\begin{array}{l}\text { Waller, Wiegmann, OI- } \\
\text { son, Rogers }\end{array}$ \\
\hline Northern Upland Non - Yard & 8 & 8 & & & Random pairs & 3 & Rogers \\
\hline Northern Upland Yard & 34 & 34 & & & Random pairs & 7 & Rogers \\
\hline Open Bog & 18 & & 18 & & NA & 0 & \\
\hline Pine Barren & 40 & 40 & & & Point-quarter & 0 & \\
\hline Prairie & 295 & 74 & 221 & & NA & 79 & $\begin{array}{l}\text { Leach, Givnish, } \\
\text { Milbauer, Kraziewski }\end{array}$ \\
\hline Rock Cliff & 37 & & 37 & & NA & 0 & \\
\hline Sand Barren & 21 & & 21 & & NA & 0 & \\
\hline Savanna & 58 & 52 & 6 & & Random pairs & 4 & Rogers \\
\hline Sedge Meadow & 79 & & 79 & & NA & 0 & \\
\hline Shrub Carr & 10 & & 10 & & NA & 0 & \\
\hline $\begin{array}{l}\text { Southern Dry Field Weed } \\
\text { Community }\end{array}$ & 33 & & 33 & & NA & 0 & \\
\hline $\begin{array}{l}\text { Southern Dry Road Weed } \\
\text { Community }\end{array}$ & 4 & & 4 & & NA & 0 & \\
\hline Southern Lowland Forest & 133 & 76 & 33 & 24 & Point-quarter & 50 & Johnson, Alsum \\
\hline $\begin{array}{l}\text { Southern Mesic Weed Com- } \\
\text { munity }\end{array}$ & 21 & & 21 & & NA & 0 & \\
\hline $\begin{array}{l}\text { Southern Railroad Weed } \\
\text { Community }\end{array}$ & 9 & & 9 & & NA & 0 & \\
\hline $\begin{array}{l}\text { Southern Rich Weed Commu- } \\
\text { nity }\end{array}$ & 15 & & 15 & & NA & 0 & \\
\hline Southern Upland Forest & 264 & 153 & 37 & 16 & Random pairs & 137 & Rogers \\
\hline Strand and Lake Dune & 35 & & 35 & & NA & 0 & \\
\hline TOTAL & 2,069 & & & & & 513 & \\
\hline
\end{tabular}




\section{Resurvey field methods}

\section{Forests}

We have invested considerable time and effort to resurvey the forested communities in an effort to document patterns of change, assess species losses, and infer the mechanisms driving ecological change (Rooney et al. 2004a, 2004b, Wiegmann and Waller 2006, Rogers et al. 2008, 2009). Although the original PEL researchers did not mark sample plots, we have generally been able to accurately relocate sites using the original PEL maps and site descriptions. Nevertheless, some are unsuitable for re-sampling due to habitat conversion or recent major disturbances such as logging (5 of 67 of the northern upland stands - Rooney et al. 2004b). Of the 114 original PEL southern upland stands with quantitative data, $14 \%$ were degraded ( 2 stands) or lost to residential or commercial use (14 stands), cattle grazing (1 stand), or cropland (1 stand). We were refused access to four sites. We systematically resurveyed most of those remaining to obtain accurate information on ecological changes in this region.

We compared forest survey methods in a separate study including the power they have to detect various kinds of change as a function of sample size (Johnson et al. 2008). These made clear that although the original overstory sampling was adequate, data from only twenty $1-\mathrm{m}^{2}$ quadrats have low statistical power for detecting changes in community composition and species abundances. To better balance our effort and more fully characterize forest communities, we now sample understory communities at higher intensities (40-120 $1-\mathrm{m}^{2}$ quadrats instead of 20). We designed these revised methods, however, to approximate the historical methods in areal extent and intensity, ensuring that we can make reliable comparisons. Because resurvey methods varied among the forest types, we do not present them in Table 2.

\section{Northern upland forests}

Our resurveys of the northern upland forests have covered a range of mixed hardwood and coniferous forest types (Rooney et al. 2004b, Wiegmann \& Waller 2006a, Amatangelo et al. 2010). In 2000-2001, we relocated and resurveyed 62 northern upland mesic sites using similar but more intensive methods (Rooney et al. 2004b, Wiegmann \& Waller 2006). At each site, after re-locating the stand, we laid out and permanently marked three $20 \mathrm{~m} \times 20 \mathrm{~m}$ plots spaced $20 \mathrm{~m}$ apart along a random direction and all at least $30 \mathrm{~m}$ from any stand edge. Within each of these tree plots (totaling 1,200 $\mathrm{m}^{2}$ ), we identified all trees $>2.5 \mathrm{~cm}$ in diameter and measured their DBH's. These provided approximately the same number of trees as in the originally surveys but provided absolute (areabased) estimates of tree density, basal area, and biomass. To characterize the understory, we noted the occurrences of all vascular plant species (including woody plants $<2.5 \mathrm{~cm} \mathrm{DBH)} \mathrm{in} 1201-\mathrm{m}^{2}$ quadrats $(6 \mathrm{x}$ the 20 quadrats sampled in the original survey). To characterize patterns of spatial contagion, we placed these in six lines of 20 contiguous $1-\mathrm{m}^{2}$ quadrats located along the first and second sides of each tree plot (Fig. 4). These plots characterize the vegetation covering about 0.5 ha of forest.

To extend our sample and further compare methods, we relocated and resampled an additional 32 dry to dry-mesic stands in 2004 using an extended version of the PEL's original method (Amatangelo et al. 2010). In particular, we used two large box transects to sample 160 trees per site and survey understory plants over 80 spaced quadrats (four replicates with the first placed to best match the original stand description).

\section{Northern lowland forests}

Lowland forests in northern Wisconsin are dominated by Larix \& Picea. Matt Bushman (Bushman 2004) revisited and resurveyed 34 of the original Curtis northern wet-mesic communities in 2005 using the same sampling techniques and intensity as used in 1952.

\section{Apostle Islands}

We resurveyed 32 forest sites in the Apostle Islands in 2005 to track changes relative to original surveys from 1958 using two distinct methods (Mudrak et al. 2009). To match the original PEL methods, we used standard $1-\mathrm{m}^{2}$ quadrats to sample understory plants at 40 points along two to four transects arranged to fit the size and/or shape of the stand. We also replicated their point-centered-quarter method to sample four trees at each point (Cottam \& Curtis 1956). Finally, we sampled saplings and shrubs within $404-\mathrm{m}^{2}$ quadrats centered on each point, extending the PEL method to provide more specific data for this important layer (e.g., Canada yew, Taxus canadensis, remains dense on islands lacking white-tailed deer but is otherwise nearly absent).
To compare classic PEL methods with the standard sampling methods of the USDA Forest Service's Forest Inventory Analysis (FIA) program (http://www.fia.fs.fed.us/), we also set up and sampled standard FIA plots (Mudrak et al. 2009, Gray et al. 2012). Briefly, the FIA method uses four $7.32 \mathrm{~m}$ radius 'subplots' arranged in a triangle with one subplot in the center. Within subplots, we identified and measured the diameter of all trees. We sampled groundlayer plants within each of three $1 \mathrm{~m}^{2}$ quadrats within each subplot as well as the DBH of all shrubs and saplings within a plot of intermediate size ( $2.07 \mathrm{~m}$ radius). While all three methods provided similar power and results for trees, both the Curtis method (based on $201-\mathrm{m}^{2}$ quadrats) and especially the FIA method (using $121-\mathrm{m}^{2}$ quadrats per site) lacked statistical power for characterizing forest understory composition and for tracking changes over time (Johnson et al. 2008).

\section{Cedar glades}

Wisconsin cedar glades are known for their rare orchids and unusual soil chemistry. Jason Mills resurveyed six stands of this type clustered near the Wisconsin River in 2004 (Mills 2008). Since the locations of the 1952 sample plots within these stands were unknown, he sampled 60 points spaced $10 \mathrm{~m}$ apart in each glade vs. the original 20 points spaced $15-20 \mathrm{~m}$ apart. Sampling otherwise followed the original design, using the random pairs technique to sample trees $>10 \mathrm{~cm}$ DBH and sampling the understory based on species presence/absence in the $1-\mathrm{m}^{2}$ quadrats. He followed the original square (or U) shape except in very steep stands where he placed three transects parallel to each other (Mills 2008).

\section{Southern upland forests}

Historically, these forests were dominated by either oak or maple canopies along a conspicuous edaphic gradient (Curtis and McIntosh 1951, Peet and Loucks 1977). Since then, oaks have declined and maples have increased across the gradient (Rogers et al. 2008), reflecting what some refer to as 'mesification' (Nowacki and Abrams 2008). A field crew led by Dave Rogers resurveyed 94 of these stands between 2002 and 2004 using methods quite similar to, but more intensive than, those used by the original researchers (Rogers et al. 2008, Rogers et al. 2009). As the exact locations of the original surveys were not known, they replicated the sampling to obtain data from four adjacent 


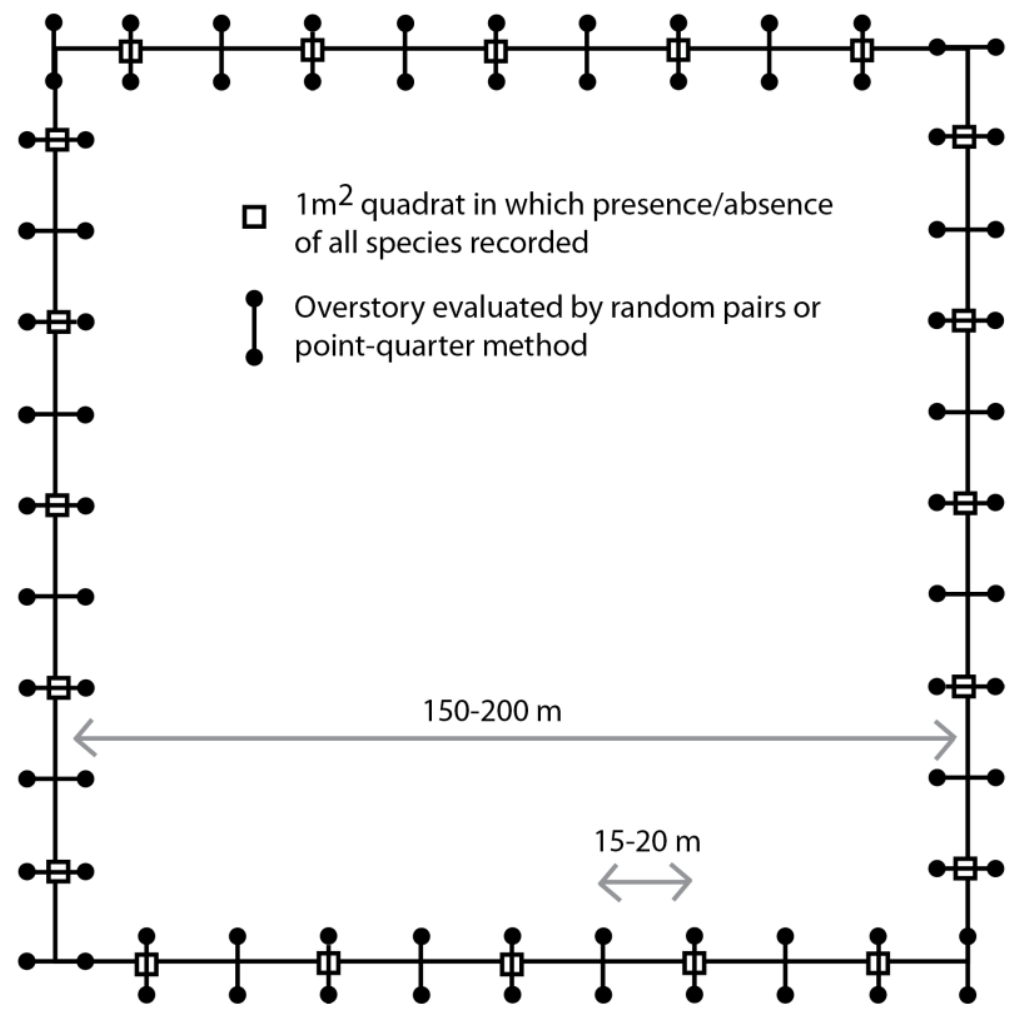

Fig. 3: Basic sampling design that J.T. Curtis and colleagues often used to sample the southern and northern upland forest stands. Researchers would begin at a corner and pace out either three perpendicular linear transects (in the shape of a large $\mathrm{U})$ or four transects in the shape of a square (as shown below). These were flexibly sized and placed to fit the size of the stand. Overstory sampling occurred at every point and $1 \mathrm{~m}^{2}$ understory quadrats were placed at every other point. In most cases, 40 points were sampled for trees and 20 for understory vascular plants.

transects providing a total of 160 measured trees at each site and 80 understory quadrats. They placed the first replicate in the location that best matched the original stand description.

\section{Southern lowland forests}

Wet floodplain forests experience frequent disturbance by floods and possess a rich diversity of sedges as well as characteristic floodplain trees including species of Ulmus, Acer, and Fraxinus. Sarah Johnson and her team resurveyed 50 lowland sites in 2007 and 2008 to assess changes in these dynamic forests. They examined changes in both overstory ( $\mathrm{S}$. Johnson \& D.M. Waller unpubl.) and understory composition. At these sites, they generally laid out six parallel $50 \mathrm{~m}$ long transects arranged perpendicular to the river or other body of water and spaced $20 \mathrm{~m}$ apart. They sampled all trees within 6-m belts flanking these transects to obtain data on tree basal area and density $\left(900 \mathrm{~m}^{2}\right.$ total) from the same average number of trees as were sampled in the sent at four times between spring and fall, 2005 and followed Anderson's original methods in sampling twenty $1-\mathrm{m}^{2}$ quadrats along two or more transects at each site in July (Kraszewski \& Waller 2008).

\section{Data structures, files, and availability}

We provide general background on history and findings of the original PEL survey work and summaries of our recent resurvey research on our own website (http://www.botany.wisc.edu/PEL/). This site also includes overviews of the communities, a number of maps, a list of many of the individuals involved in these efforts, and an updated list of publications from the group.

As noted above, many of the original legacy Curtis data are available in Lotus 1-2-3 format via the public website: http://www.stolaf.edu/people/ceumb/PEL. html (but see caveats above regarding data quality). We have re-transcribed the original PEL survey data for the particular sites that we have resurveyed and checked these data to ensure minimal errors and taxonomic oddities. These data are available by request from our group. We encourage researchers to learn more about these data and consider using them in their own research.

Analyses of the resurvey data are contributing to our understanding of plant species and community dynamics including patterns of species loss and gain, plant traits associated with shifts in abundance, and shifts in patterns of alpha and beta diversity including widespread homogenization (e.g., Leach \& Givnish 1996, Rooney et al. 2004b, Wiegmann \& Waller 2006, Rogers et al. 2008). We have also begun to explore effects of landscape conditions on these dynamics in the context of understanding the 'extinction debt' and the other forces driving ecological change in these systems (e.g., Rogers et al. 2009). Because these survey-resurvey data were laborious to collect and synchronize and because comparing these data sets demands care in analysis and interpretation, we encourage others interested in working with these then vs. now data to contact us. These issues also led us to develop explicit recommendations and guidelines for using these data (see: http://www.botany.wisc.edu/PEL/Data_us e.html). In general, these explain that we release data initially to collaborators then to others as we have the chance to complete our planned papers. We encourage 
researchers to contact us to discuss access and potential collaborative use and to respect these data use policies.

\section{Discussion}

The original PEL researchers spent much time and energy surveying plant community variation at over 2000 sites in Wisconsin (Fralish et al. 1993). Their efforts succeeded in providing one of the most complete and quantitative snapshots we have of plant communities in the 1940s and 1950s (see http://www.botany.wisc. edu/PEL/data.html). Their efforts to compile and carefully archive these data provide us with an exceptional baseline for inferring ecological change. Our recent resurveys of these sites provide remarkably detailed pictures of how these communities have changed over the last half century (e.g., Rooney et al. 2004b, Rogers et al. 2008, 2009, S. Johnson \& D.M. Waller unpubl.). They also provide a new baseline for assessing future changes. The large number of sites and species and the 50 or more years that have elapsed since the PEL participants began their work give us high statistical power for detecting ecological changes and for testing the factors associated with them. These studies also reveal important differences among sites (Rogers et al. 2009) and species (e.g., Wiegmann \& Waller 2006) that illuminate the likely drivers of change across the region. The generality of these drivers means such changes are likely to be typical in temperate communities around the world (Waller \& Rooney 2008).

Results so far demonstrate general principles that we expect plant communities to obey at macroscopic scales. Not surprisingly, communities within larger contiguous patches of habitat support higher species richness and, indeed, the single best variable for predicting a species' persistence at a site is its initial abundance. Including these variables and relationships in statistical models allow us to investigate additional factors and finerscale patterns with greater precision and less bias. We are now comparing the rates of decline and increase in the abundances of particular species to assess how plant characteristics (functional traits) affect their responses to various presumed drivers of ecological change. The trends in species gains and losses that we observe in prairies are strongly linked to both phylogeny and to plant traits like stature, $\mathrm{N}$ fixation, seed size (Leach \& Givnish
1996). In the northern forests, modes of pollination and dispersal and the fiber and protein content of leaves affect shifts in species abundance (Wiegmann \& Waller 2006). In the southern forests, plants of different growth form (tree, shrub, herb, or graminoid) have differed conspicuously in dynamics since the 1950s (Rogers et al. 2008). These results help us to understand how plant traits interact with external shifts in environmental conditions to affect species and community dynamics.

We are also comparing patterns of community change among sites that differ in surrounding landscape conditions to assess how landscape conditions affect patterns of diversity and the dynamics of particular species. The broad spectrum of species and communities sampled provides considerable power not only for detecting changes but also for identifying the particular drivers of ecological change in our region.

We expected to observe some of the changes we have documented: succession toward more mesic forests in the absence of fire, invasions of weedy exotic species, conspicuous overall declines in community diversity, declines in beta diversity, and more fragmented forests losing species faster than larger and more continuous stands. Losses of rare and more specialized species coupled with increases in common and widespread species contribute to regional homogenization and associated declines in beta diversity (McKinney \& Lockwood 1999, Olden 2006). Other results are more surprising: stands with no hunting have lost far more species than hunted stands (stands in two unhunted State Parks lost $>50 \%$ of their species), declines in (re)-colonization have contributed more to diversity declines than increases in extinction (probably reflecting fragmentation effects); and local site conditions (canopy and soil nutrients) that strongly predicted herb community composition in the 1950s now appear less important than surrounding landscape conditions. In general, classical ecological predictions based on succession and local gradients are losing value while landscape conditions and biotic interactions are becoming more important. These results illustrate how fundamental changes can occur that would be invisible without quality baseline data (Magnuson 1990).

\section{Acknowledgements}

The paper was conceived and outlined by all the authors. D.W. and K.A. collaborat- ed on writing the paper after D.R. and S.J. provided details on the roles of particular researchers, PEL history, site selection and re-location criteria, and field methods. W.S. Alverson, R. Peet, and G. Sonnier provided constructive edits and suggestions. O. Loucks, G. Struik (Bray), and M. Christensen, participants in the early PEL studies, provided useful background and details. The original research of J.T. Curtis and his PEL students was supported by the Wisconsin Alumni Research Foundation, the Office of Naval Research, and the U.S. National Science Foundation (NSF). We are also grateful to the USDA - NRI CSREES program (grants: 2003-02472 and 2008-3532018680) and the NSF-Ecology program (grants DEB 023633 and 0717315) for supporting the re-surveys described here.

\section{References}

Amatangelo, K.L., Fulton, M.R., Rogers,D.A., Waller, D.M. (2010): Convergence in forest community composition along an edaphic gradient threatens landscape-level diversity. - Diversity and Distributions 17: 201-213. CrossRef

Anderson, O. (1954): The phytosociology of dry lime prairies of Wisconsin. - PhD thesis, University of Wisconsin [deposited at the UW Memorial Library, Madison]

Bray, J.R. (1955): The savanna vegetation of Wisconsin and an application of the concepts order and complexity to the field of ecology. - PhD thesis, University of Wisconsin [deposited at the UW Memorial Library, Madison].

Bray, J.R., Curtis, J.T. (1957): An ordination of the upland forest communities of southern Wisconsin. - Ecological Monographs 27: 325-349. CrossRef

Brown, R.T., Curtis, J.T. (1952): The upland conifer-hardwood forests of northern Wisconsin. - Ecological Monographs 22: 217-234. CrossRef

Burgess, R.L. (1993): J.T. Curtis: botanist, ecologist, conservationist. - In: Fralish, J.S., McIntosh, R.P., Loucks,O.L. [Eds.]: Fifty years of Wisconsin plant ecology: 1-43. Madison: Wisconsin Academy of Sciences.

Bushman, M.M. (2004): Plant species changes in Northern Wisconsin wetmesic forest communities from 1952 to 2005. - Stevens Point: University of Wisconsin.

Christensen, M. (1969): Soil microfungi of dry to mesic conifer-hardwood forests in northern Wisconsin. - Ecology 50: 9-27. CrossRef

Christensen, M. (1989): A view of fungal ecology. - Mycologia 81: 1-19. CrossRef 
Cottam, G., Curtis, J.T. (1949): A method for making rapid surveys of woodlands by means of pairs of randomly selected trees. - Ecology 30: 101-104. CrossRef

Cottam, G., Curtis, J.T. (1956): The use of distance measures in phytosociological sampling. - Ecology 37: 451-460. CrossRef

Curtis, J.T. (1959): The Vegetation of Wisconsin. - Madison, WI: University of Wisconsin Press.

Curtis, J.T., Greene, H.C. (1949): A study of relic Wisconsin prairies by the species-presense method. - Ecology 30: 83-92. CrossRef

Curtis, J.T., Mclntosh, R.P. (1951): An upland forest continuum in the prairieforest border region of Wisconsin. Ecology 32: 476-496. CrossRef

Fralish, J.S., Mclntosh, R.P., Loucks, O.L. (1993) [Eds.]: John T. Curtis: Fifty years of Wisconsin plant ecology. - Madison, WI: Wisconsin Academy of Sciences, Arts, and Letters.

Gleason, H.A. (1926): The individualistic concept of the plant association. Bulletin of the Torrey Botanical Club 53: 7-26. CrossRef

Gleason, H.A., Cronquist, A. (1991): Manual of vascular plants of northeastern United States and adjacent Canada, 2nd ed. - New York: The New York Botanical Garden.

Gray, A.N., Brandeis, T.J., Shaw, J.D., McWilliams, W.H., Miles, P.D. (2012): Forest Inventory and Analysis Database of the United States of America (FIA). In: Dengler, J., Oldeland, J., Jansen, F., Chytrý, M., Ewald, J., Finckh, M., Glöckler, F., Lopez-Gonzalez, G., Peet, R.K., Schaminée, J.H.J. (2012) [Eds.]: Vegetation databases for the 21st century. - Biodiversity \& Ecology 4: 225-231. Hamburg: Biocentre Klein Flottbek and Botanical Garden. CrossRef

Hansen, M.M., Olivieri, I., Waller, D.M., Nielsen, E.E. (2012): Monitoring adaptive genetic responses to environmental change. - Molecular Ecology 21: 13111329. CrossRef

Johnson, S.E., Mudrak, E.L., Waller, D.M. (2008): Comparing power among three sampling methods for monitoring forest vegetation. - Canadian Journal of Forest Research 38: 143-156. CrossRef

Kraszewski, S.E., Waller, D.M. (2008): Fifty-five year changes in species composition on dry prairie remnants in southcentral Wisconsin. - Journal of the Torrey Botanical Society 135: 236-244. CrossRef
Leach, M.K., Givnish, T.J. (1996): Ecological determinants of species loss in remnant prairies. - Science 273: 15551558. CrossRef

Magnuson, J.J. (1990): Long-term ecological research and the invisible present: Uncovering the processes hidden because they occur slowly or because effects lag years behind causes. - BioScience 40: 495-501. CrossRef

McKinney, M.L., Lockwood, J.L. (1999): Biotic homogenization: a few winners replacing many losers in the next mass extinction. - Trends in Ecology and EvoIution 14: 450-453. CrossRef

Mills, J.E. (2008): Fifty years of change in Wisconsin cedar glades. - American Midland Naturalist 159: 214-224. CrossRef

Mudrak, E.L., Johnson, S.E., Waller, D.M. (2009): Forty-seven year changes in vegetation at the Apostle Islands: effects of deer on the forest understory. - Natural Areas Journal 29: 167-176. CrossRef

Nowacki, G.J. Abrams, M.D. (2008): The demise of fire and "mesophication" of the eastern United States. - BioScience 58: 123-128. CrossRef

Olden, J.D. (2006): Biotic homogenization: a new research agenda for conservation biogeography. - Journal of Biogeography 33: 2027-2039. CrossRef

Peet, R.K., Loucks, O.L. (1977): A gradient analysis of Southern Wisconsin forests. - Ecology 58: 485-499. CrossRef

Rogers, D.A., Rooney, P.T., Hawbaker, T.J., Radeloff, V.C., Waller, D.M. (2009): Paying the extinction debt in Southern Wisconsin forest understories. - Conservation Biology 23: 1497-1506. CrossRef

Rogers, D.A., Rooney, T.P., Waller, D.M. (2008): Fifty years of change in southern Wisconsin forests: Shifts in canopy and understory richness, composition and heterogeneity. - Ecology 89: 24822492. CrossRef

Rooney, T.P., Rogers, D.A., Wiegmann, S.M., Waller, D.M. (2004a.): Monitoring non-native plant invasions over 50 years in Wisconsin forests. - Weed Technology 18: 1266-1268. CrossRef

Rooney, T.P., Wiegmann, S.M., Rogers, D.A., Waller, D.M. (2004b.) Biotic impoverishment and homogenization in unfragmented forest understory communities. - Conservation Biology 18: 787798. CrossRef

Struik, G.J., Curtis, J.T. (1962): Herb distribution in an Acer saccharum forest. -
American Midland Naturalist 68: 285296. CrossRef

Voss, E.G. (1972): Michigan flora. Part I: Gymnosperms and monocots. - Bloomfield Hills, Michigan: Cranbrook Institute of Science.

Voss, E.G. (1985): Michigan flora. Part II: Dicots (Saururaceae - Cornaceae). Bloomfield Hills, Michigan: Cranbrook Institute of Science.

Voss, E.G. (1996): Michigan flora. Part III: Dicots (Pyrolaceae - Compositae). Bloomfield Hills, Michigan: Cranbrook Institute of Science.

Waller, D.M., Rooney, T.P. (2008) [Eds.]: The vanishing present: Wisconsin's changing lands, waters, and wildlife. Chicago, IL: University of Chicago Press.

Whittaker, R.H. (1956): Vegetation of the Great Smoky Mountains. - Ecologcial Monographs 26: 1-80. CrossRef

Whittaker, R.H. (1975): Communities and ecosystems. 2nd ed. - New York: Macmillian.

Wiegmann, S.M., Waller, D.M. (2006): Biotic homogenization in forest understories: identity and traits of historical "winners" and "losers". - Biological Conservation 129: 109-123. CrossRef

Donald M. Waller* (dmwaller@wisc.edu) Department of Botany, University of Wisconsin - Madison

430 Lincoln Drive

Madison, WI 53706, UNITED STATES

Kathryn L. Amatangelo

(kamatang@gmail.com)

Department of Ecology and Evolutionary

Biology, Brown University

Providence, RI, UNITED STATES

Sarah Johnson (sjohnson@northland.edu) Department of Biology, Northland

College

Ashland, WI, UNITED STATES

David A. Rogers (rogdave@gmail.com)

Department of Biological Sciences,

University of Wisconsin - Parkside

Kenosha, WI, UNITED STATES

*Corresponding author 